\title{
Oestrogen-dependent expression of LH/hCG receptors in pig Fallopian tube and their role in relaxation of the oviduct
}

\author{
B. Gawronska ${ }^{1}$, T. Paukku' ${ }^{2}$, I. Huhtaniemi² ${ }^{2}$, G. Wasowicz ${ }^{1}$ and A. J. Ziecik ${ }^{1 *}$ \\ ${ }^{1}$ Institute of Animal Reproduction and Food Research of Polish Academy of Sciences, ul. Tuwima 10, 10-747 Olsztyn 5, PO Box 55 , \\ Poland; and 'Department of Physiology, University of Turku, Finland
}

\begin{abstract}
The current studies investigated the concentration and distribution of LH receptors in the oviduct of ovariectomized gilts at various times after administration of oestradiol benzoate $\left(10 \mu \mathrm{g} \mathrm{kg}^{-1}\right.$ body weight) to determine whether $\mathrm{LH}$ participates in the regulation of oviductal contractions. Polyclonal antibodies to the $\mathrm{LH}$ receptor were used in immunocytochemical and western blot analyses of oviductal tissues. The mechanical activity of the isthmus and ampullar segments of oviduct, collected from 16 cyclic gilts, was recorded for $30 \mathrm{~min}$ after LH or hCG treatment. In the oviduct, there was little competition for receptor occupancy between hCG and pig FSH, bovine thyroid-stimulating hormone (TSH), pig growth hormone (GH) and pig prolactin (1.2, $0.1,0.01$ and $<0.001 \%$, respectively) but pig LH could completely inhibit the binding of [125I]hCG. Oestradiol benzoate increased $(P<0.01)$ the number of $\mathrm{LH}$ binding sites in oviduct 24,48 and $72 \mathrm{~h}\left(0.60 \pm 0.08,1.62 \pm 0.15,2.48 \pm 0.35 \mathrm{fmol} \mathrm{mg}^{-1}\right.$ protein; $n=4$ per treatment, respectively) after injection compared with the control gilts treated with corn oil $\left(0.20 \pm 0.04 \mathrm{fmol} \mathrm{\textrm {mg } ^ { - 1 }}\right.$ protein; $\left.n=4\right)$. The affinity of oviductal $\mathrm{LH} / \mathrm{hCG}$ binding sites $\left(K_{\mathrm{a}}\right)$ varied from 4.0 to $8.5 \times 10^{10} 1 \mathrm{~mol}^{-1}$ and was similar to that of luteal cell binding sites $\left(6.1 \times 10^{10} \mathrm{l} \mathrm{mol}^{-1}\right)$. Oestradiol benzoate also resulted in more intense $\mathrm{LH}$ receptor immunostaining of the tubal mucosal epithelium, smooth muscle cells and blood vessels as compared with controls. Western blotting has revealed that the pig oviduct, similar to the corpus luteum, contains 75,48 and $45 \mathrm{kDa}$ immunoreactive $\mathrm{LH}$ receptor proteins. Treatment with $\mathrm{LH}$ in vitro $\left(100 \mathrm{ng} \mathrm{ml}^{-1}\right)$ affected the contractility of oviduct. During the peri-ovulatory stage of the oestrous cycle, the amplitude, frequency and area under curve(s) of the isthmus decreased $(P<0.05)$, as did the frequency and area under curve $(P<0.05$ and $P<0.01$, respectively) of the ampulla $(n=4)$. The frequency and area under curve of the oviductal contractions were also significantly reduced during the early follicular phase of the oestrous cycle $(P<0.05)$. There was no effect of LH (or hCG) on the frequency and area under curve of the oviductal contractions during luteal stages of the oestrous cycle $(n=8)$. These data indicate that $(1)$ the pig oviduct possesses immunoreactive and functional $\mathrm{LH}$ receptor, (2) oestradiol promotes the synthesis of LH receptor in the epithelium and smooth muscles, and (3) LH causes the relaxation of oviduct, especially during the peri-ovulatory stage of the oestrous cycle. In summary, the results of the present study indicate that LH can control oviductal contractions directly and may be partially responsible for the relaxation of isthmus during fertilization in pigs.
\end{abstract}

\section{Introduction}

$\mathrm{LH}$ and its agonist, $\mathrm{hCG}$, play a crucial role in the regulation of gonadal physiology. However, the existence of specific, high-affinity, low capacity binding sites for LH/hCG has been reported in the pig (Ziecik et al., 1986), rabbit (Jensen and Odell, 1988; Sawitzke and Odell, 1991), rat (Bonnamy et al., 1990; Sawitzke and Odell, 1991), bovine (Friedman et al.,

${ }^{*}$ Correspondence.

Received 18 June 1998.
1995) and human uterus (Reshef et al., 1990; Bhattacharya et al., 1993). Moreover, LH/hCG receptors are present in the myometrium (Reshef et al., 1990; Környei et al., 1993), endometrium (Reshef et al., 1990; Bhattacharya et al., 1993) as well as in the uterine broad ligament (Ziecik et al., 1995). The myometrial LH/hCG receptors play a role in uterine hyperplasia and hypertrophy (Környei et al., 1993), as well as in uterine motility (Flowers et al., 1991; Ziecik et al., 1993; Eta et al., 1994), and hCG has a relaxing effect on pig (Flowers et al., 1991; Ziecik et al., 1993) and human (Eta et al., 1994) myometrium. 
$\mathrm{LH} / \mathrm{hCG}$ receptors are also present in the human Fallopian tube (Lei et al., 1993). The tubal receptors are present mainly in mucosal cells, but also in the smooth muscle and blood vessels (Lei et al., 1993). LH receptors have not yet been detected in the pig oviduct, but Derecka et al. (1995) showed the presence of LHR mRNA in the pig oviduct during the early luteal and follicular phase of the oestrous cycle. Given the extragonadal expression of the LH/hCG receptors, the purpose of the present study was to examine their regulation and function by assessing (a) the effect of oestradiol on the capacity and affinity of the LH/hCG binding sites in crude oviductal membrane fractions, and their distribution in the pig oviduct, and (b) to study the effect of LH on the contractility of different segments of the pig oviduct in vitro.

\section{Materials and Methods}

\section{Hormone preparations}

Purified hCG (CR-127; $14900 \mathrm{iu} \mathrm{mg}^{-1}$ ) and bovine TSH (bTSH 11; NIH, Bethesda, MD) was provided by the National Hormone and Pituitary Program (NIDDKD, Rockville, MD). Pig prolactin (Biolactin; $19 \mathrm{iu} \mathrm{mg}^{-1}$ ) was a gift of F. Ryszka (Silesian School of Medicine, Zabrze), and pig FSH (pFSHB1), pig LH (pLH B-1; 1.7 iu mg ${ }^{-1}$ ) and pig GH (pGH B-1; $1.54 \mathrm{iu} \mathrm{mg}^{-1}$ ) was donated by the USDA Hormone Program, Bethesda, MD. Oestradiol benzoate was purchased from Polfa (Jelenia Góra).

\section{Animals and experimental procedures}

Sexually mature (8-10 months of age; $100-120 \mathrm{~kg}$ ) crossbred gilts were ovariectomized under general anaesthesia $1 \mathrm{month}$ before the first experiment. The animals were premedicated with Combelen (Biowet, Pulawy). As soon as the gilts became somnolent, anaesthesia was induced and maintained with Vetbutal (Biowet; about $15-20 \mathrm{ml}$ i.v.) through an ear vein. The ovariectomized animals received an i.m. injection of $2 \mathrm{ml}$ oestradiol benzoate ( $1 \mathrm{mg} 100 \mathrm{~kg}^{-1}$ body weight) $24 \mathrm{~h}(n=4), 48 \mathrm{~h}(n=4)$ or $72 \mathrm{~h}(n=4)$ before slaughter. Controls $(n=4)$ were given an i.m. injection of $2 \mathrm{ml}$ corn oil $48 \mathrm{~h}$ before slaughter. The genital tracts were removed within $10 \mathrm{~min}$ after slaughter and transported on ice to the laboratory in less than $2 \mathrm{~min}$. The tubes were carefully dissected from extraneous tissues. One Fallopian tube was used for LH/hCG receptor measurements and western blot analysis; the other was used for immunocytochemistry.

In the second experiment, oviducts were collected from 16 mature crossbred gilts. The animals were kept in separate pens and checked daily for heat in the presence of a boar. The first day of behavioural oestrus was established as day 0 of the oestrous cycle. The days of the oestrous cycle were additionally confirmed by the morphological appearance of the ovaries after slaughter (Akins and Morrisette, 1968; Leiser et al., 1988). These parameters allowed the classification of the oviduct tissues into four major groups: (1) peri-ovulatory stage: days $18-2(n=4)$; (2) early luteal stage: days 5-8 $(n=4)$; (3) late luteal stage: days 13-15 $(n=4)$; and (4) early follicular stage: days 16-17 $(n=4)$. In both experiments, gilts were slaughtered at the Institute's abattoir. The oviducts were collected $10 \mathrm{~min}$ after slaughter, placed immediately in cold Krebs' solution, transported to the laboratory and dissected. Subsequently, tissues were placed in tissue chambers within 15-20 min of death.

All experiments were performed in accordance with Guiding Principles for the Care and Use of Research Animals and the internal instructions of the Institute's Director.

\section{$L H / h C G$ receptor binding analyses}

Tissue (oviducts from ovariectomized gilts in the first experiment and corpora lutea from mid-cycle gilts in the second experiment) were dissected, minced with scissors and weighed. The cell membrane fractions were obtained using the procedure described by Ziecik et al. (1986). Briefly, the tissues were homogenized in four bursts of $7 \mathrm{~s}$ at $4^{\circ} \mathrm{C}$ with an Ultra-Turrax homogenizer in six volumes $(\mathrm{w} / \mathrm{v})$ of $0.025 \mathrm{~mol}$ Tris- $\mathrm{HCl} \mathrm{l}^{-1}$ buffer $\mathrm{pH} 7.4$, containing $0.25 \mathrm{~mol}$ of sucrose $\mathrm{l}^{-1}$. The homogenate was then filtered through four layers of cheesecloth, and the filtrate centrifuged for $20 \mathrm{~min}$ at $800 \mathrm{~g}$ at $4^{\circ} \mathrm{C}$. The resulting supernatant was centrifuged further for $1 \mathrm{~h}$ at $25000 \mathrm{~g}$ at $4^{\circ} \mathrm{C}$ and the sediment

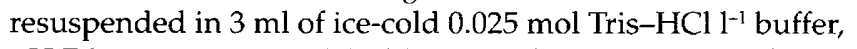
$\mathrm{pH} 7.2$, containing $0.1 \%(\mathrm{w} / \mathrm{v}) \mathrm{BSA}$ and $5 \mathrm{mmol} \mathrm{MgCl}_{2} \mathrm{l}^{-1}$. The resulting suspension was stored at $-70^{\circ} \mathrm{C}$ for further experimentation. A fraction of the membrane preparation without BSA addition was used for protein determination using the method of Lowry et al. (1951).

Human CG (CR-127) was labelled by the Iodogen method (Fraker and Speck, 1978). Na[ ${ }^{125 I}$ [iodide was purchased from Amersham International (Amersham, Bucks). The separation of protein-bound and free $\left[{ }^{125} \mathrm{I}\right]$ was performed by chromatography on Sephadex G-50 (Pharmacia, Uppsala) columns $(1 \mathrm{~cm} \times 15 \mathrm{~cm})$. The specific activity of the labelled hCG was determined by self displacement analysis on corpus luteum membrane preparations in the radioligand receptor assay (Ketelslegers et al., 1975), and it varied from $50 \times 10^{3}$ to $70 \times 10^{3}$ c.p.m. ng $^{-1}$.

The cell membrane fraction was incubated with tracer in polystyrene tubes for $16 \mathrm{~h}$ at room temperature. The incubation mixture consisted of $0.1 \mathrm{ml} 0.025 \mathrm{mmol}$ Tris- $\mathrm{HCl}$ $\mathrm{l}^{-1}(\mathrm{pH} 7.2)$ containing $5 \mathrm{mmol} \mathrm{MgCl}_{2} \mathrm{l}^{-1}$ and $0.1 \%(\mathrm{w} / \mathrm{v}) \mathrm{BSA}$ (incubation buffer), $0.1 \mathrm{ml}$ incubation buffer containing 25000 c.p.m. [ $\left.{ }^{125} \mathrm{I}\right]$ iodo-hCG and $0.2 \mathrm{ml}$ of the receptor preparation. Preliminary experiments showed that binding of labelled hCG was proportional to the amount of receptor added from 0.6 to $2 \mathrm{mg}$ protein of oviductal cell membrane preparation. Nonetheless, $1.0 \mathrm{mg}$ receptor protein was used consistently to determine binding parameters in oviduct and $0.4 \mathrm{mg}$ in corpora lutea and these values were normalized per milligram of protein for the presentation of data.

Two millilitres ice-cold incubation buffer was added at the end of the incubation period and the tubes were centrifuged at $1000 \mathrm{~g}$ for $30 \mathrm{~min}$. The supernatants were removed by aspiration and the radioactivity of the pellets was determined in a $\gamma$-spectrometer with $75 \%$ counting efficiency. Non-specific binding was determined in the presence of 0.5 
$\mu$ g unlabelled hCG, and was found to be $<5 \%$ of the total ${ }^{125} \mathrm{I}$ label added.

The receptor concentration and equilibrium association constant $\left(K_{a}\right)$ of unoccupied binding sites were determined by Scatchard (1949) analysis. Six to eight subsaturating doses (0.03-5.00 ng) of unlabelled hCG were used for each receptor preparation in duplicate.

\section{Immunoperoxidase staining of $L H / h C G$ receptor}

Three portions of each oviduct (isthmus, ampulla and infundibulum) were fixed for $6 \mathrm{~h}$ in $4 \%(\mathrm{w} / \mathrm{v})$ paraformaldehyde in $0.1 \mathrm{~mol}$ PBS $1^{-1}$. Fixed tissues were stored in $18 \%(\mathrm{w} / \mathrm{v})$ sucrose in PBS with $0.01 \%(\mathrm{w} / \mathrm{v})$ sodium azide. Cryostat sections $(8 \mu \mathrm{m})$ were air-dried, rinsed in 0.05 mol Tris-hydroxylmethyl aminomethane $\mathrm{l}^{-1}$-buffered saline $1^{-1}$ (TBS), pH 7.6, and then placed in ethanol in ascending concentration series $(50 \%, 70 \%, 96 \%$ of absolute alcohol). The sections were treated with $1 \%(\mathrm{v} / \mathrm{v}) \mathrm{H}_{2} \mathrm{O}_{2}$ in methanol for 30 min to block endogenous peroxidases, and then in $0.75 \%$ $(\mathrm{w} / \mathrm{v})$ glycine in TBS for $30 \mathrm{~min}$ to block free aldehyde groups. After rinsing in TBS, the sections were incubated overnight with primary antibody (diluted 1:200; a rabbit polyclonal antiserum directed against the amino acids 15-38 of the N-terminal sequence of the rat LH receptor; a courtesy of P. C. Roche, Mayo Clinic, Rochester, MN). Antibody binding was detected with the ABC complex (avidinbiotin-horseradish peroxide complex; Vectastain ABC kit from Vector Laboratories, Inc. Burlingame, CA). Peroxidase activity was revealed using 3,3'-diaminobenzidine as a substrate. Two types of controls were performed: (1) the primary antibody was omitted during the immunostaining procedure; (2) the primary antibody was substituted with non-specific immunoglobulin $G$ (IgG) during the immunostaining procedure. The observations and photographs were made using a light microscope (Olympus IMT-2) equipped with Nomarsky optics.

\section{Measurement of oviductal contractility in vitro}

The tubes were dissected carefully from the mesosalpinx, utero-ovarian ligament and other surrounding tissues. Rings (3-4 mm long) from isthmus and ampullar parts of oviduct were dissected to explore the contractile activity of Fallopian tube. All these tubal manipulations were performed while the oviduct was immersed in chilled Krebs' solution. The preparations were then mounted in $5 \mathrm{ml}$ tissue chambers containing Krebs' solution $\left(120.3 \mathrm{mmol} \mathrm{NaCl} \mathrm{^{-1 }}, 5.9 \mathrm{mmol}\right.$ $\mathrm{KCl} \mathrm{l}^{-1}, 2.5 \mathrm{mmol} \mathrm{CaCl}, \mathrm{l}^{-1}, 1.2 \mathrm{mmol} \mathrm{MgCl}_{2} \mathrm{l}^{-1}, 1.2 \mathrm{mmol}$ $\mathrm{NaH}_{2} \mathrm{PO}_{4} \mathrm{l}^{-1}, 15.5 \mathrm{mmol} \mathrm{NaHCO}_{3} \mathrm{l}^{-1}, 11.5 \mathrm{mmol}$ glucose $\mathrm{l}^{-1}$; $\mathrm{pH} 7.4$ ) that were exposed continuously to a mixture of $95 \%$ $\mathrm{O}_{2}: 5 \% \mathrm{CO}_{2}$ at $37^{\circ} \mathrm{C}$. Two consecutive rings of ampulla or isthmus were used simultaneously in two separate tissue chambers. The rings were tied vertically at each edge with cotton threads; one edge was attached to an isometric smooth muscle transducer (HSE Isometric Force Transducer F30 Type 372, March-Freiburg) which was coupled to a physiological pen recorder (Graphtec-Watanabe Oscillo- graphic Recorder WR 3320 Mark VII, Type MK7-2DL) under a passive tension of $10 \mathrm{mN}$, and the other was tied to a hook at the bottom of the bath. The mechanical activity was recorded $30 \mathrm{~min}$ after the muscle began to contract spontaneously and it showed a stable pattern of rhythmic contractions. LH or hCG was added to the tissue chambers and the mechanical activity was recorded for the next 30 min. After changing Krebs' solution, tissues recovered to resting contraction within about $20-30 \mathrm{~min}$ and only segments maintaining the ability to contract were used in the final analysis. The chart speed was set at $25 \mathrm{~mm} \mathrm{~min}^{-1}$ to allow for analysis of areas under the curves (AUC).

Frequency, amplitude and AUC measurements were carried out for three different 10 min periods: I, 10 min before the addition of hormone to the tissue chamber; II, $10 \mathrm{~min}$ after addition of the hormone; and III, between 20 and 30 min after the addition of the hormone. The measurement alone during period I served as control for measurements II and III, which were expressed as percentages of measurement I. A similar method was used in a study by Ekerhovd et al. (1997).

\section{Western blotting}

Membrane fractions of oviducts and corpora lutea were prepared as described by Ziecik et al. (1986) with the exception that $0.2 \mathrm{~mol}$ Tris- $\mathrm{HCl} \mathrm{l}^{-1}, \mathrm{pH} 7.2$ buffer, containing $0.1 \mathrm{~mol}$ phenylomethylsulphonyl fluoride $\mathrm{l}^{-1}$ to inhibit the protein activity, was used. Aliquots $(70 \mu \mathrm{g})$ of protein were dissolved in double-strength loading buffer consisting of 0.5 mol Tris- $\mathrm{HCl} \mathrm{l}^{-1}$ ( $\mathrm{pH} \mathrm{6.8),} \mathrm{4 \%} \mathrm{(w/v)} \mathrm{SDS,} \mathrm{20 \%} \mathrm{(v/v)} \mathrm{glycerol}$ and $2 \%(\mathrm{v} / \mathrm{v}) 2$-mercaptoethanol and separated on $10 \%(\mathrm{w} / \mathrm{v})$ SDS-PAGE (polyacrylamide gel electrophoresis in the presence of SDS). The separated proteins were electroblotted onto $0.1 \mu \mathrm{m}$ nitrocellulose membranes for $2 \mathrm{~h}$ at $250 \mathrm{~mA}$ in a 0.025 mol Tris- $\mathrm{HCl} \mathrm{^{-1 }}$ buffer ( $\mathrm{pH} \mathrm{8.2)}, 0.192 \mathrm{~mol}$ glycine $\mathrm{l}^{-1}$, containing $0.1 \%(\mathrm{w} / \mathrm{v})$ SDS. The non-specific binding sites were blocked with $5 \%(\mathrm{w} / \mathrm{v})$ non-fat dry milk in $0.1 \mathrm{~mol}$ Tris-HCl l-1 $\left(\mathrm{pH} \mathrm{7.4)}, 0.15 \mathrm{~mol} \mathrm{NaCl} \mathrm{l}^{-1}, 0.1 \%\right.$ (v/v) Tween-20 (TBST buffer) overnight at $4^{\circ} \mathrm{C}$. The membranes were then incubated with a $1: 1000$ dilution of the $\mathrm{LH}$ receptor antibody (PR) for $1.5 \mathrm{~h}$ at $22^{\circ} \mathrm{C}$ and washed three times for $10 \mathrm{~min}$ each with TBST. The washed blots were reincubated for $1 \mathrm{~h}$ at $22^{\circ} \mathrm{C}$ with a 1:3000 dilution of biotinylated antirabbit IgG, washed with TBST and incubated for $1 \mathrm{~h}$ at $22^{\circ} \mathrm{C}$ with $1: 3000$ dilution of $\mathrm{ABC}$ complex (Vectastain $\mathrm{ABC}$ kit, Vector Laboratories, Inc, Burlingame, CA). TBS containing $0.01 \%$ $(\mathrm{v} / \mathrm{v}) \mathrm{H}_{2} \mathrm{O}_{2}$ and $0.04 \%(\mathrm{w} / \mathrm{v}) 3,3^{\prime}$-diaminobenzidine was used to develop colour

\section{Statistical analysis}

The data were analysed by ANOVA followed by Duncan's new multiple range post-hoc test. The results are expressed as means \pm SEM. The number of tubal preparations $n$ was equal to the number of animals per group since one segment of isthmus or ampulla from each gilt was taken for measurement of oviductal contractility in vitro. 


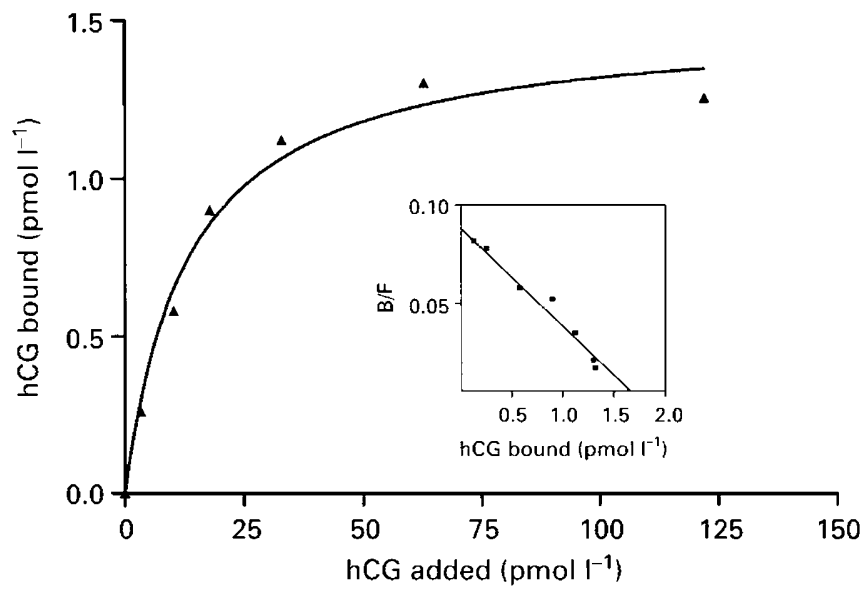

Fig 1. Saturation curve and Scatchard plot of hCG binding to pig oviductal membrane preparation. $K_{\mathrm{a}}=4.9 \times 10^{111} \mathrm{I} \mathrm{mol}^{-1}$.

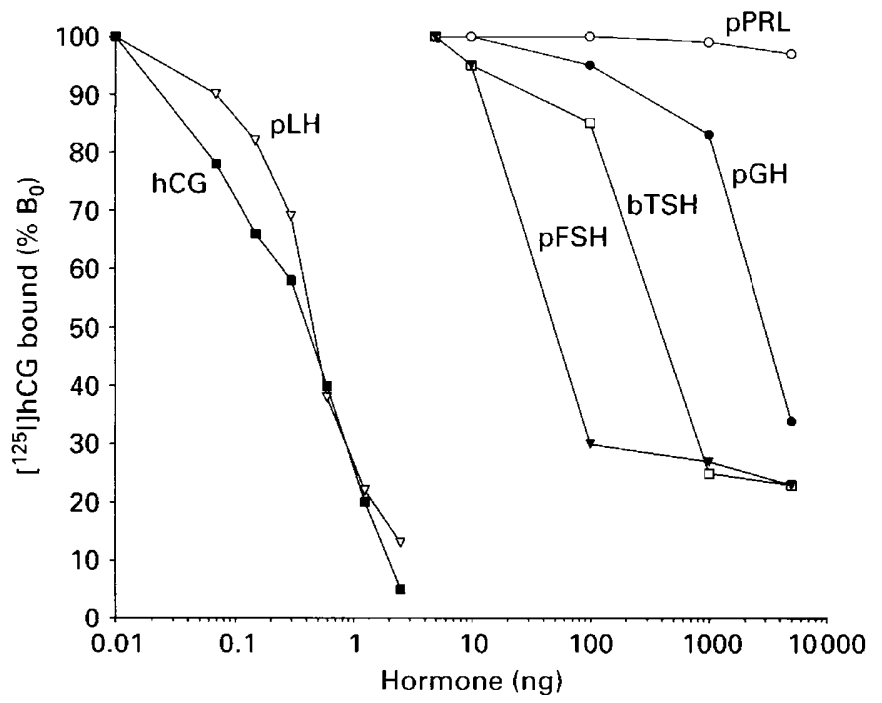

Fig. 2. Hormonal specificity of ${ }^{125} \mathrm{I}$-labelled hCG to pig oviduct. Crude membrane preparation (1 mg protein) of oestradiol-treated gilts was incubated with 25000 c.p.m. of ${ }^{125} \mathrm{I}$-labelled hCG in the presence of increasing amounts of hormones. Means of duplicates from a representative of two experiments (with a mixed receptor sample from control and oestradiol-treated gilts) are shown. GH, growth hormone; PRL, prolactin; TSH, thyroid-stimulating hormone.

\section{Results}

\section{Concentration of $L H / h C G$ receptor in oviduct}

The number of $\mathrm{LH} / \mathrm{hCG}$ receptors and their apparent association constant $\left(K_{\mathrm{a}}\right)$ were measured at equilibrium (Fig. 1). The Scatchard plots prepared from oviductal tissues were linear (Fig. 1). The specificity of $\left[{ }^{125} \mathrm{I}\right] \mathrm{hCG}$ binding to oviductal cell membrane preparations is shown (Fig. 2). There was very little competition between $\mathrm{hCG}$ and $\mathrm{pFSH}$, bTSH, pGH and pig prolactin $(1.2,0.1,0.01$ and $<0.001 \%$, respectively) but pLH could completely inhibit the binding

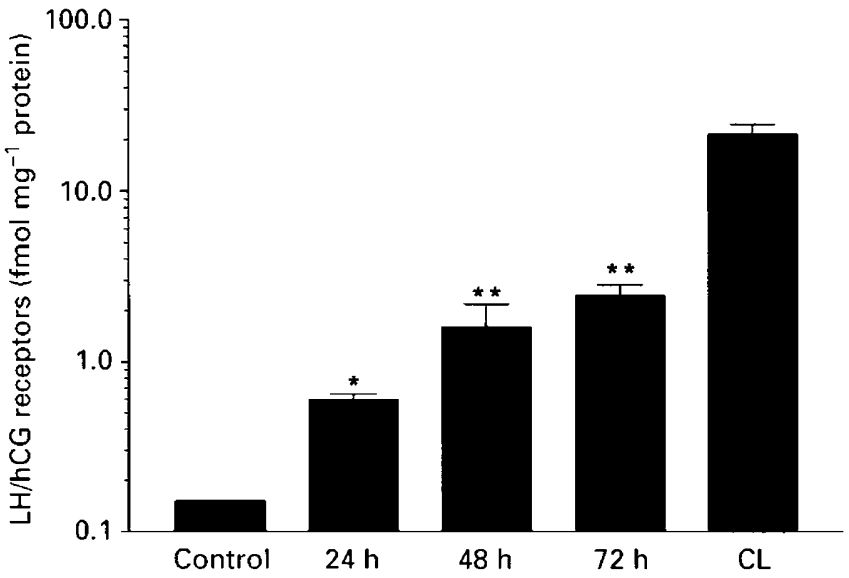

Fig. 3. Concentration of $L H / h C G$ receptors (means $\pm S E M$ ) in the oviduct of control (ovariectomized) gilts, and those ovariectomized and treated with oestradiol benzoate 24,48 and $72 \mathrm{~h}$ before tissue collection. Corpora lutea $(\mathrm{CL})$ from mid-cycle mature gilts represent a positive control tissue. Asterisks indicate values significantly different from controls, ${ }^{*} P<0.05 ;{ }^{* *} P<0.01$.

of $\left[{ }^{125} \mathrm{I}\right] \mathrm{hCG}$. The gilts treated with oestradiol benzoate had a higher $(P<0.05-0.01)$ concentration of oviductal LH $/$ hCG receptors than those given corn oil (Fig. 3). The effect was time-dependent, without affecting the receptor affinity. This parameter $\left(K_{\mathrm{a}}\right)$ averaged between $4.0 \times 10^{10}$ and $8.5 \times 10^{10}$ $1 \mathrm{~mol}^{-1}$ for control gilts and those treated for various times with oestradiol benzoate. The affinity of uterine LH/hCG binding sites of oviduct was similar to that measured for corpus luteum $\left(K_{\mathrm{a}}=6.1 \times 10^{10} \mathrm{l} \mathrm{mol}^{-1}\right)$. However, the number of binding sites in the oviductal tissue of gilts treated with oestradiol benzoate $\left(0.60-2.48 \mathrm{fmol} \mathrm{mg}^{-1}\right.$ protein) was $4-30$ fold less $(P<0.01)$ than the receptor binding of the pig corpora lutea $\left(16.8 \pm 2.4 \mathrm{fmol} \mathrm{mg}^{-1}\right.$ protein). The specificity of [ ${ }^{125}$ I] $\mathrm{hCG}$ binding to other tissues was determined by incubating crude membrane preparations of skeletal muscle and kidney. Only non-specific binding of [ $\left.{ }^{125} \mathrm{I}\right] \mathrm{hCG}$ was found in these tissues.

\section{Immunoperoxidase staining of $L H / h C G$ receptor}

The immunostaining of gilt oviducts for the $\mathrm{LH}$ receptor are shown (Figs 4 and 5). This immunostaining was absent when the receptor antibody was omitted or substituted with non-specific immunoglobulin $G \quad(\operatorname{IgG})$ during the immunostaining procedure (Fig. $4 \mathrm{l}$ ). Three parts of the pig oviduct, the isthmus (Fig. 4a,d,g,j), ampulla (Fig. 4b,e,h,k) and infundibulum (Fig. 4c,f,i), were immunopositive for the $\mathrm{LH}$ receptor. Immunoreactivity for $\mathrm{LH}$ receptor in the Fallopian tube sections was seen in the epithelium of the tubal mucosa, smooth muscle cells and the blood vessel endothelium (Fig. 4a-k). Tubal sections from control pigs revealed only minor LH receptor immunostaining (Fig. $4 a-c)$. In all pigs treated with oestradiol, the most noticeable immunostaining was seen in the mucosal epithelium (Fig. $4 \mathrm{e}-\mathrm{k}$ ), where the apical regions of epithelial cells had more intense staining then the underlying cytoplasm. The muscle 

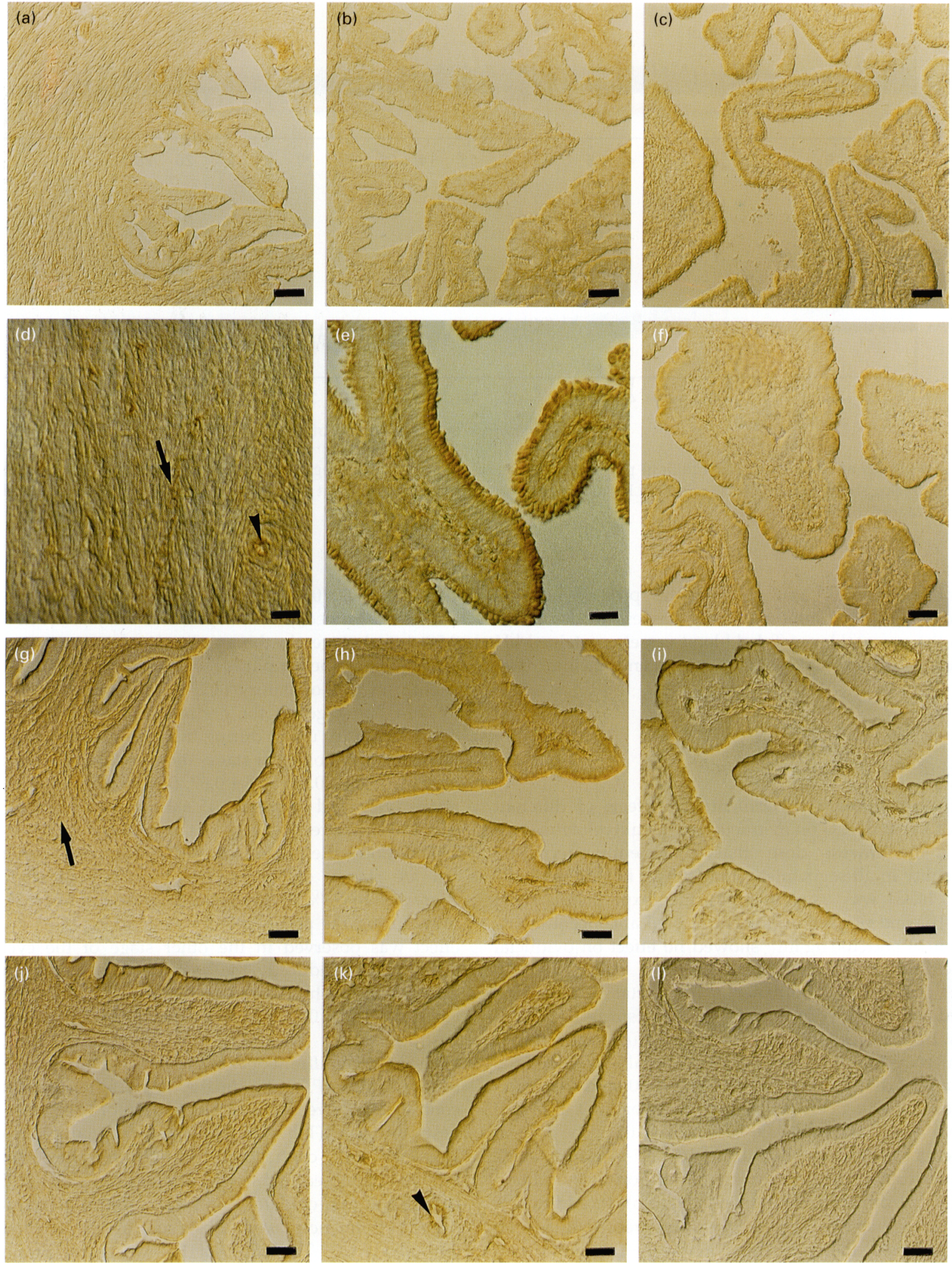

Fig. 4. Immunocytochemistry for $\mathrm{LH} / \mathrm{hCG}$ receptors in the gilt oviduct. (a,b,c) Ovariectomized controls; (d,e,f) ovariectomized gilts treated with oestradiol benzoate $24 \mathrm{~h}$ before tissue collection; ( $\mathrm{g}$,h,i) ovariectomized gilts treated with oestradiol benzoate $48 \mathrm{~h}$ before tissue collection; ( $\mathrm{j}, \mathrm{k}, \mathrm{l})$ ovariectomized gilts treated with oestradiol benzoate $72 \mathrm{~h}$ before tissue collection; (l) Control in which nonspecific IgG was substituted for primary antibody. $(\mathrm{a}, \mathrm{d}, \mathrm{g}, \mathrm{j}, \mathrm{l})$ Isthmus; $(\mathrm{b}, \mathrm{e}, \mathrm{h}, \mathrm{k})$ ampulla; $(\mathrm{c}, \mathrm{f}, \mathrm{i})$ infundibulum. Arrowheads represent a positive reaction in endothelial cells of blood vessels; arrows represent a positive reaction in the smooth muscle cells. Scale bars represent $(\mathrm{a}-\mathrm{c}, \mathrm{f}-\mathrm{l}) 250 \mu \mathrm{m}$ and $(\mathrm{d}, \mathrm{e}) 500 \mu \mathrm{m}$. 
(a)

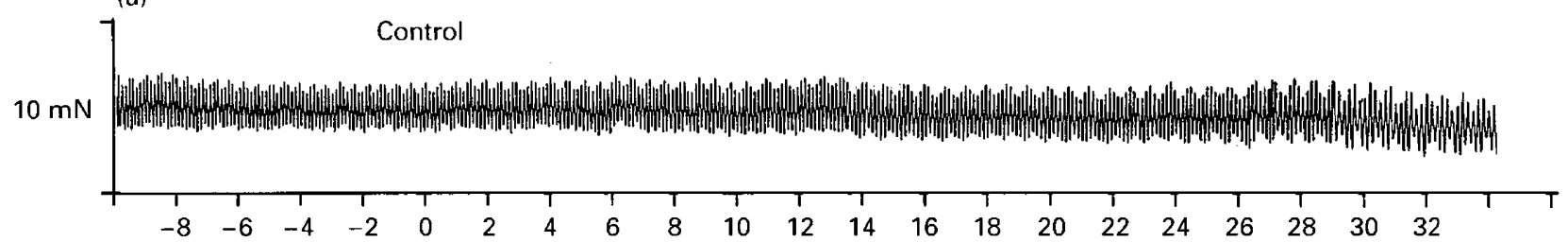

(b)

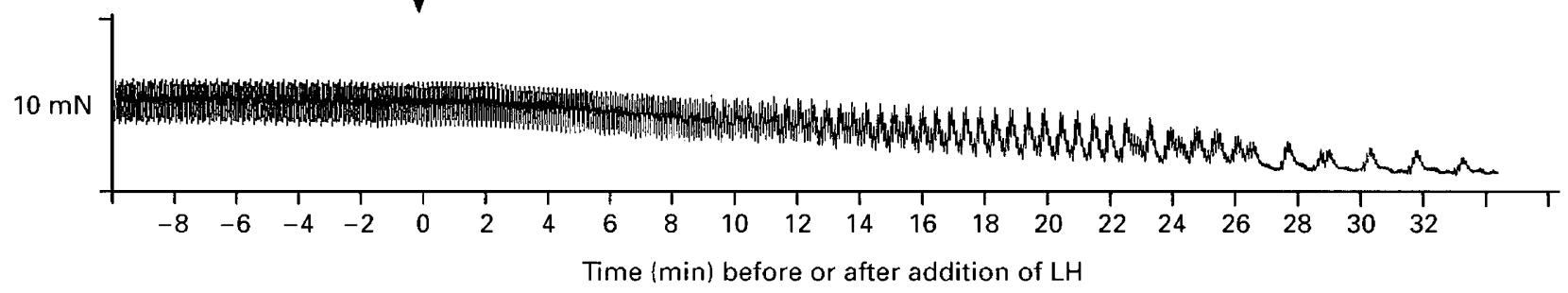

Fig. 5. A typical control (without LH addition) polygraph tracing of the isthmus ring segment of a pig oviduct (a), and a representative myograph tracing showing the relaxing effect of LH on the pig oviduct isthmus ring segment (b). Both oviducts were collected during the periovulatory stage of the oestrous cycle.

cells of myosalpinx also showed the presence of LH receptors (Fig. $4 \mathrm{~d}, \mathrm{~g}, \mathrm{j}$ ), but the staining was less intense than it was in the mucosal layer. Tubal blood vessels contained LH receptors, but these were limited to the endothelium (Fig. $4 d, k)$.

\section{Contractility of oviductal segments}

In the preliminary experiment, the effects of different doses of LH and hCG on oviductal contractility in vitro were tested. The lowest dose that consistently decreased contractility in all segments tested $\left(100 \mathrm{ng} \mathrm{LH} \mathrm{ml}^{-1}\right.$ and 134 $\mathrm{ng} \mathrm{ml}^{-1} \mathrm{hCG}$ ) was used in all further experiments. FSH (pFSH-B1) and prolactin (Biolactin) tested at concentrations between 20 and $100 \mathrm{ng} \mathrm{ml}^{-1}$ showed no effect on oviductal contractility.

The pattern of spontaneous oviductal contractions differed among the various stages of the oestrous cycle. The highest frequencies of isthmic contractions (contractions per $10 \mathrm{~min}$ ) were found during the early luteal stage (167.50 \pm $17.50)$ and early follicular stage $(98.80 \pm 6.90)$ and compared with lower frequencies in the peri-ovulatory $(60.40 \pm 9.60)$ and late luteal stages $(64.00 \pm 8.50 ; P<0.05)$. The typical contractions of the isthmus during the peri-ovulatory stage of the oestrous cycle are shown without hormone addition (Fig 5a) and during LH treatment (Fig. 5b). In addition, a higher frequency of contractions was recorded in the ampulla during the early luteal phase $(99.50 \pm 8.50)$ than during the peri-ovulatory, late luteal and follicular stages of the oestrous cycle $(52.20 \pm 7.20,61.70 \pm 5.00$ and $55.00 \pm 4.60$, respectively). The early luteal stage was characterized by the lowest amplitude (tissue tension; $\mathrm{mN}$ ) of isthmus contractions $(0.48 \pm 0.05)$ and compared with the periovulatory, late luteal and follicular stages $(3.73 \pm 0.47 ; 3.18 \pm$
1.80 and $1.28 \pm 0.20$, respectively; $P<0.05$ ). There was no difference between the early $(2.52 \pm 1.10)$ and late $(2.73 \pm$ $0.58)$ luteal stages in the amplitude of contractions in the ampulla, but the amplitude of this contraction increased slightly in peri-ovulatory $(4.27 \pm 0.62)$ and early follicular $(3.50 \pm 0.70)$ stages of the oestrous cycle. The areas under curve (arbitrary units) during the peri-ovulatory, early and late luteal, and follicular stages did not differ significantly in isthmus $(5.98 \pm 0.28 ; 5.38 \pm 0.67 ; 5.28 \pm 0.87$ and $6.58 \pm 0.40$, respectively) and ampulla $(6.45 \pm 0.46 ; 4.80 \pm 0.09 ; 5.67 \pm 0.31$ and $4.70 \pm 0.54$, respectively) of the oviduct.

The contractile parameters of the isthmus in response to $\mathrm{LH}$ are shown (Table 1). The frequency of contraction decreased by $23 \% 20-30 \mathrm{~min}$ after addition of LH $(P=0.06)$ only during the peri-ovulatory stage of oestrous cycle; no effect was observed in the other stage of the cycle. LH significantly reduced the amplitude of spontaneous contractions of the isthmus in the peri-ovulatory $(P<0.05)$, early luteal $(P<0.05)$ and late luteal $(P<0.05)$ stages of the oestrous cycle. The reduction of isthmic AUC was statistically significant only in the peri-ovulatory stage of the oestrous cycle $(P<0.05)$. In the ampulla, the frequency of contractility decreased after LH addition in all stages of the oestrous cycle (Table 2). However, the reduction of the frequency of contractions $20-30 \mathrm{~min}$ after hormone administration reached statistical significance $(P<0.05)$ only during the peri-ovulatory and early follicular stages. The highest differences were observed in the reduction of ampullar AUC. The effect of LH was most pronounced during the peri-ovulatory $(P<0.01)$ and early follicular stages $(P<0.05)$. LH reduced the ampullar AUC up to 65.5 and $79.5 \%$ of controls in the peri-ovulatory and early follicular stages, respectively $(P<0.05-0.01)$. The results indicate that LH had the most pronounced effect on the inhibition of spontaneous contractions in vitro in both the 
Table 1. Mean ( \pm SEM) frequency, amplitude and area under curves of spontaneous contraction of the pig isthmus collected during different stages of the oestrous cycle and incubated with $100 \mathrm{ng} \mathrm{LH} \mathrm{ml}^{-1}$

\begin{tabular}{|c|c|c|c|c|c|c|}
\hline \multirow{2}{*}{$\begin{array}{l}\text { Stage of } \\
\text { oestrous cycle }\end{array}$} & \multicolumn{2}{|c|}{ Frequency } & \multicolumn{2}{|c|}{ Amplitude } & \multicolumn{2}{|c|}{ Area under curves } \\
\hline & II & III & II & III & II & III \\
\hline $\begin{array}{l}\text { Days } 18-2 \\
\text { (peri-ovulatory) }\end{array}$ & $101.1 \pm 9.3$ & $77.4 \pm 7.8$ & $83.4 \pm 8.6$ & $68.4 \pm 7.3^{*}$ & $87.2 \pm 5.1$ & $70.9 \pm 8.7^{*}$ \\
\hline $\begin{array}{l}\text { Days 5-8 } \\
\text { (early luteal) }\end{array}$ & $94.5 \pm 5.9$ & $98.7 \pm 0.7$ & $105.8 \pm 4.0$ & $79.2 \pm 3.8^{*}$ & $97.9 \pm 8.1$ & $91.2 \pm 12.8$ \\
\hline $\begin{array}{l}\text { Days13-15 } \\
\text { (late luteal) }\end{array}$ & $104.3 \pm 6.9$ & $82.3 \pm 11.8$ & $93.1 \pm 6.9$ & $59.4 \pm 15.1^{*}$ & $104.3 \pm 4.3$ & $87.1 \pm 9.7$ \\
\hline $\begin{array}{l}\text { Days } 16-17 \\
\text { (early follicular) }\end{array}$ & $94.9 \pm 3.1$ & $99.5 \pm 4.21$ & $112.7 \pm 11.9$ & $112.8 \pm 15.7$ & $100.2 \pm 2.9$ & $94.5 \pm 9.4$ \\
\hline
\end{tabular}

The responses are expressed as percentage of initial values (period I: from 10 to $0 \mathrm{~min}$ before hormone treatment; period II: from 0 to $10 \mathrm{~min}$; and period III: from 20 to $30 \mathrm{~min}$ after $\mathrm{LH}$ addition).

$* P<0.05$ versus period $\mathrm{I}$ in rows.

Table 2. Mean ( \pm SEM) frequency, amplitude and area under curves of spontaneous contraction of the pig ampulla collected during different stages of the oestrous cycle and incubated with $100 \mathrm{ng} \mathrm{LH} \mathrm{ml} \mathrm{LH}^{-1}$

\begin{tabular}{|c|c|c|c|c|c|c|}
\hline \multirow{2}{*}{$\begin{array}{l}\text { Stage of } \\
\text { oestrous cycle }\end{array}$} & \multicolumn{2}{|c|}{ Frequency } & \multicolumn{2}{|c|}{ Amplitude } & \multicolumn{2}{|c|}{ Area under curves } \\
\hline & II & III & II & III & II & III \\
\hline $\begin{array}{l}\text { Days } 18-2 \\
\text { (peri-ovulatory) }\end{array}$ & $87.7 \pm 3.8$ & $71.1 \pm 11.5^{*}$ & $100.6 \pm 9.0$ & $69.8 \pm 17.2$ & $89.8 \pm 3.6$ & $65.5 \pm 11.2^{* *}$ \\
\hline $\begin{array}{l}\text { Days 5-8 } \\
\text { (early luteal) }\end{array}$ & $89.4 \pm 0.4$ & $70.4 \pm 13.5$ & $84.0 \pm 19.0$ & $86.7 \pm 13.3$ & $108.6 \pm 9.3$ & $90.3 \pm 5.7$ \\
\hline $\begin{array}{l}\text { Days 13-15 } \\
\text { (late luteal) }\end{array}$ & $96.8 \pm 2.5$ & $87.2 \pm 9.1$ & $88.7 \pm 11.8$ & $75.8 \pm 14.2$ & $95.3 \pm 4.2$ & $91.1 \pm 5.5$ \\
\hline $\begin{array}{l}\text { Days } 16-17 \\
\text { (early follicular) }\end{array}$ & $98.9 \pm 2.5$ & $93.5 \pm 1.6^{*}$ & $92.0 \pm 5.1$ & $88.7 \pm 6.7$ & $95.6 \pm 1.8$ & $79.5 \pm 7.5^{*}$ \\
\hline
\end{tabular}

The responses are expressed as percentage of initial values (period I: from 10 to 0 min before hormone treatment; period II: from 0 to $10 \mathrm{~min}$; and period III: from 20 to $30 \mathrm{~min}$ after $\mathrm{LH}$ addition).

$* P<0.05 ;{ }^{* *} P<0.01$ versus period $I$ in rows.

isthmus and ampulla during the peri-ovulatory stage of oestrous cycle (Tables 1 and 2). The inhibition of the amplitude and frequency of the contractions, as well as the reduction of the AUCs, took place gradually in about $10 \mathrm{~min}$ after the LH addition (Fig. 5).

\section{LH/hCG receptor protein}

Western blotting with polyclonal $\mathrm{LH} / \mathrm{hCG}$ receptor antibody showed that oviducts contained 75,48 and $45 \mathrm{kDa}$ proteins in all pigs treated with oestradiol (Fig. 6, lanes 1 and 2). Corpora lutea contained the same 75,48 , and $45 \mathrm{kDa}$ receptor proteins (Fig. 6, lane 3). The skeletal muscle did not show receptor protein (data not shown).

\section{Discussion}

These experiments provide evidence that the pig oviduct is a target organ for LH. The immunocytochemical studies revealed that $\mathrm{LH}$ receptors are present mainly in the mucosal epithelial cells of the oviduct, which is in agreement with a previous study of Lei et al. (1993) of the human oviduct. The presence of $\mathrm{LH} / \mathrm{hCG}$ receptor mRNA transcripts in human (Lei et al., 1993) and pig (Derecka et al., 1995) oviducts, as well as receptor protein in cultured mucosal cells of the human oviduct (Han et al., 1996), has been reported. Comparison of the immunostaining intensities revealed that the cells of myosalpinx expressed lower amounts of LH/hCG receptors than the epithelial mucosal cells of pig oviduct. A similar distribution of LH receptors was found in women (Lei et al., 1993). LH/hCG receptors in smooth muscle cells were also found in the myometrial cells of pigs (Ziecik et al., 1986) and women (Reshef et al., 1990; Környei et al., 1993), and in the superficial smooth muscle cell layer of the broad ligament in pigs (Ziecik et al., 1995).

Western blotting studies showed that pig corpora lutea and oviducts contain mainly $75 \mathrm{kDa}$ receptor species, which corresponds to a calculated molecular mass for $\mathrm{LH}$ receptor in pigs (Loosfelt et al., 1989). However, in the present study, the $75 \mathrm{kDa}$ band is rather the glycosated $68 \mathrm{kDa}$ form 


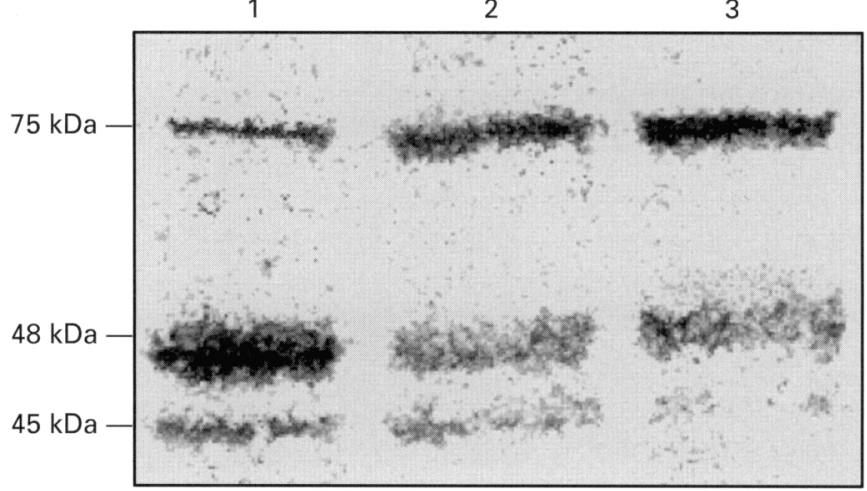

Fig. 6. Western immunoblotting for LH/hCG receptors. Lane 1, oviduct from ovariectomized gilt treated with oestradiol benzoate 48 h before tissue collection; lane 2, oviduct from ovariectomized gilt treated with oestradiol benzoate $24 \mathrm{~h}$ before tissue collection; lane 3 , pig corpora lutea. Forty milligrams of protein of each tissue was used.

described by Vu Hai-Luu Thi et al. (1992) in pig testis. The 48 and $45 \mathrm{kDa}$ receptor variants detected in pig corpora lutea and oviducts are apparently forms lacking transmembrane or intracellular domains. Comparison of the results of the present study with previous results revealed that the receptors in pig oviduct do not differ qualitatively and quantitatively from those in the other extragonadal positive tissues (myometrium, endometrium and umbilical cord). The negative control tissues, liver, kidney and skeletal muscle, do not contain $\mathrm{LH}$ receptors.

The oviduct is a natural extension of the uterine horn and both structures share a common origin from Müllerian ducts (Hunter, 1988); therefore, it is not surprising that LH receptors are present in the oviduct. Oviductal LH binding was dependent on oestradiol stimulation as is LH binding in the myometrium (Flowers et al., 1991). The results of the present study showed that LH inhibited the amplitude of isthmic contractions in gilts from peri-ovulatory, early luteal and late luteal stages of the oestrous cycle, as well as reducing the AUC of the isthmus during the peri-ovulatory stage. In the ampulla, $\mathrm{LH}$ reduced the AUC and the frequency of contractility in gilts from the peri-ovulatory and early follicular stages of the oestrous cycle. Hence, LH can modulate the spontaneous contractions of the pig oviduct directly. In all cases, gradual inhibition of the spontaneous contractions were observed within $10 \mathrm{~min}$ after the addition of LH (or hCG; data not shown). LH inhibited the frequency and amplitude and reduced the AUC particularly in the isthmus and ampulla of the peri-ovulatory stage. The site of the effect is in agreement with the radioligand and immunocytochemical studies showing that oestradiol can be responsible for the expression of $\mathrm{LH}$ receptors in the pig oviduct.

The relaxing effect of gonadotrophin on smooth muscle contraction in the reproductive tract has been reported. Flowers et al. (1991) showed that hCG has a quiescent effect on myometrial spontaneous contractility, reducing the frequency and amplitude of spontaneous contractions only in gilts treated with oestradiol benzoate. Similar results were obtained during the studies in vivo of Ziecik et al. (1993), in which it was demonstrated that hCG treatment decreased the myometrial electrical activity in pigs primed with oestogen. In the human myometrium, Eta et al. (1994) found that hCG can inhibit the amplitude of oxytocin-stimulated contractions directly during the proliferative, but not the secretory, phase of the cycle. Although the mechanism of the LH effect on oviduct is not clear, it is possible that it acts through receptors situated both in epithelial and smooth muscle cells. Han et al. (1996) reported that cultured cells of human oviductal mucosa respond to hCG stimulation with increased cyclooxygenase 2 mRNA expression and protein concentrations, and with increased $\mathrm{PGE}_{2}$ production ( $\mathrm{PGE}_{2}$ is an important factor known to cause oviductal relaxation). However, LH can affect oviductal smooth muscle cell contractions directly through an increase in cAMP accumulation, as was found in pig myocytes (Kisielewska et al., 1996).

The major function of the Fallopian tube is the transport of gametes to the ampullary-isthmic junction, the usual site of fertilization and transport of embryos to the uterus. Two basic mechanisms are involved in this transport: the beat of cilia and the waves of smooth muscle activity in the myosalpinx (Hunter, 1988). Many studies show that ovarian steroid hormones (Hunter, 1988; Ayad et al., 1994), the autonomic nervous system (Rodriquez-Martinez, 1984; Kaleczyc, 1994), prostaglandins (Spilman, 1974; Borda et al., 1980; Rodriquez-Martinez and Einarsson, 1985) and endothelin (McGovern et al., 1992; Rosseli et al., 1994) are involved in control of oviductal function. Hunter (1984) suggested that ovulation can somehow co-ordinate the transport of gametes in the pig oviduct to the ampullar-isthmic junction. However, the transport of spermatozoa from the isthmus to the site of fertilization was synchronized by ovulation in the New World monkey, Cebus apella (Oritz et al., 1995), although the exact nature of the mechanism controlling the passage of gametes and synchronizing the process of fertilization remains unknown (Hunter, 1988; Ito et al., 1991). Stimulation with oestradiol for 24-72 h caused a significant increase in LH/hCG receptors in the oviduct of ovariectomized gilts. The duration of the natural 'surge' of oestradiol that triggers the initiation of the pre-ovulatory LH surge in intact, cyclic gilts is about $48-72 \mathrm{~h}$ (Brinkley, 1981; Ziecik et al., 1987). Under normal physiological conditions, it is possible to increase $\mathrm{LH} / \mathrm{hCG}$ receptors in the pig oviduct and to prepare it for LH action. In the present in vitro studies of oviduct contractility, the greatest effect of LH on relaxation of oviduct occurred during the peri-ovulatory stage of the oestrous cycle. The results of this investigation indicate that $\mathrm{LH}$ should be added to the list of factors affecting oviduct function. We hypothesize that the pre-ovulatory surge of $\mathrm{LH}$, in addition to causing the rupture of follicles and luteinization of granulosa and theca cells, also plays an important role in controlling oviductal contractions, and is a major factor responsible for opening the ampulla-isthmic junction for spermatozoa and for synchronization of fertilization of ova in the ampulla. The relaxing action of LH may also facilitate the passage of embryos through the isthmus towards the uterus.

This study was supported by the Committee of Scientific Research in Poland (grant Nos 5 PO6K 03909 and 5 P06D 047 14) and 
Finnish-Polish Academies of Sciences Exchange Collaborative Program. Some of the results were communicated in preliminary form at the Winter Meeting of the Society for the Study of Fertility, 18-20 December 1997, London. Abstract 55.

\section{References}

Akins EL and Morrisette MC (1968) Gross ovarian changes during estrous cycle of swine American Journal of Veterinary Research 29 1953-1975

Ayad VJ, Gilbert CL, McGoff SA, Matthews EL and Wathes DC (1994) Action of oxytocin and vasopresin on estrogen-induced electromyographic activity recorder from the uterus and oviduct of anoestrous ewes Reproduction Fertility and Development 6 203-209

Bhattacharya S, Banerjee J and Leymarie P (1993) Human chorionic gonadotropin binding sites in the human endometrium Acta Endocrinologica (Copenhagen) 129 15-19

Bonnamy PJ, Benhaim A and Leymarie P (1990) Oestrous cycle-related changes of high affinity luteinizing hormone/human chorionic gonadotropin binding sites in the rat uterus Endocrinology 126 1264-1269

Borda ES, Speziale NB, Borda LJ, Gimeno MF and Gimeno AL (1980) Contractile characteristics of fimbrial, isthmic, ampullar, and fimbrioampullar segments of isolated sow (Sus scrofa) oviducts as influenced by ovulation, adrenergic mechanisms, and prostaglandin $\mathrm{E}_{1}$ International Journal of Fertility $2528-35$

Brinkley HJ (1981) Endocrine signalling and female reproduction Biology of Reproduction 24 22-43

Derecka K, Pietilä EM, Rajaniemi HJ and Ziecik AJ (1995) Cycle dependent $\mathrm{LH} / \mathrm{hCG}$ receptor gene expression in porcine nongonadal reproductive tissues Journal of Physiology and Pharmacology 46 77-85

Ekerhovd E, Brännström M, Alexandersson M and Norström A (1997) Evidence for nitric oxide mediation of contractile activity in isolated strips of the human Fallopian tube Human Reproduction 12 301-305

Eta E, Ambrus G and Rao ChV (1994) Direct regulation of human myometrial contractions by human chorionic gonadotropin Journal of Clinical Endocrinology and Metabolism 79 1582-1586

Flowers B, Ziecik AJ and Caruolo EV (1991) Effects of human chorionic gonadotrophin on contractile activity of steroid-primed pig myometrium in vitro. Journal of Reproduction and Fertility $92425-432$

Fraker G and Speck JC (1978) Protein and cell membrane iodinations with a sparingly soluble chloramine, 1,3,4,6-tetrachloro-3 $\alpha, 6 \alpha$ diphenyglycoluril Biochemical and Biophysical Research Communications 80 849-857

Friedman S, Gurevich M and Shemesh M (1995) Bovine cyclic endometrium contains high-affinity luteinizing hormone/human chorionic gonadotropin binding sites Biology of Reproduction 52 1020-1026

Han SW, Lei ZM and Rao ChV (1996) Upregulation of cyclooxygenase-2 gene expression by chorionic gonadotropin in mucosal cells from human Fallopian tubes Endocrinology $1372929-2937$

Hunter RHF (1984) Pre-ovulatory arrest and peri-ovulatory redistribution of competent spermatozoa in the isthmus of the pig oviduct journal of Reproduction and Fertility 72 203-211

Hunter RHF (1988) Transport of gametes, selection of spermatozoa and gamete lifespans in the female tract. In The Fallopian Tubes: Their Role in Fertility and Infertility pp 53-78 Ed. RHF Hunter. Springer-Verlag, Berlin, Heidelberg

Ito M, Smith TT and Yanagimachi R (1991) Effect of ovulation on sperm transport in the hamster oviduct Journal of Reproduction and Fertility 93 157-163

Jensen JD and Odell WD (1988) Identification of LH/hCG receptors in rabbit uterus Proceedings of Society of Experimental Biology and Medicine 18928-30

Kaleczyc J (1994) Effect of estradiol and progesterone on noradrenaline content in nerves of the oviduct, uterus and vagina in ovariectomized pigs Folia Histochemica et Cytobiologica 32 119-126
Ketelslegers JM, Knott GD and Catt KJ (1975) Kinetics of gonadotropin binding by receptors of the rat testis. Analysis by a nonlinear curve-fitting method Biochemistry 14 3075-3083

Kisielewska J, Flint APF and Ziecik AJ (1996) Phospholipase C and adenylate cyclase signalling systems in the action of hCG on porcine myometrial smooth muscle cells Journal of Endocrinology 148 175-180

Kömyei JL, Lei ZM and Rao ChV (1993) Human myometrial smooth muscle cells are novel targets of direct regulation by human chorionic gonadotropin Biology of Reproduction 49 1149-1157

Lei ZM, Toth P, Rao ChV and Pridham D (1993) Novel coexpression of human chorionic gonadotropin ( $\mathrm{hCG}$ )/human luteinizing hormone receptors and their ligand hCG in human Fallopian tubes Journal of Clinical Endocrinology and Metabolism 77 863-872

Leiser R, Zimmermann W, Sidler $\mathbf{X}$ and Christen A (1988) Normal-zyklische Erscheinungen im Endometrium und am Ovar des Schweines Tierärztliche Praxis 16 261-280

Loosfelt H, Misrahi M, Atger M, Salesse R, Vu Hai-Luu Thi MT, Jolivet A, Guiochon-Mantel A, Sar S, Jallal B, Garnier J and Milgrom E (1989) Cloninig and sequencing of porcine LH-hCG receptor cDNA: variants lacking transmembrane domain Science 245 525-528

Lowry OH, Rosebrough NJ, Farr AL and Randall RJ (1951) Protein measurement with the Folin phenol reagent Journal of Biological Chemistry 193 265-275

McGovern PG, Goldsmith LT, Schmidt CL, von Hagen S, Linden $M$ and Weiss G (1992) Effects of endothelin and relaxin on rat uterine segment contractility Biology of Reproduction 46 680-685

Ortiz ME, Valdez E, Gajardo G, Leon CG, Herrera E and Croxatto HB (1995) Sperm migration through the female genital tract of the New World Monkey Cebus apella. Biology of Reproduction 50 845-854

Reshef E, Lei ZM, Rao ChV, Pridham DD, Chegini N and Luborsky JL (1990) The presence of gonadotropin receptors in nonpregnant human uterus, human placenta, fetal membranes, and decidua tubes journal of Clinical Endocrinology and Metabolism 70 421-430

Rodriguez-Martinez H (1984) Effects of adrenergic agents on the in vitro motility of porcine oviduct Zentralbtatt für Veterinäermedizin Reihe A 31 91-104

Rodriguez-Martinez H and Einarsson S (1985) Influence of prostaglandins on the spontaneous motility of pig oviducts Animal Reproduction Sciences 8 259-279

Rosseli M, Imthur B, Macas E, Keller PJ and Dubey RK (1994) Endogenous nitric oxide modulates endothelin- 1 induced contraction of bovine oviduct Biochemical and Biophysical Research Communications 201 143-148

Sawitzke AL and Odell WD (1991) Uterine binding sites for LH/hCG can be modulated by hormonal status in rabbits and rats Acta Endocrinologica (Copenhagen) 124 322-330

Scatchard G (1949) The attraction of proteins for small molecules and ions Annals of New York Academy of Sciences 51 660-672

Spilman CH (1974) Oviduct motility in the rhesus monkey: spontaneous activity and response to prostaglandins Fertility and Sterility 25 935-945

Vu Hai-Luu Thi MT, Misrahi M, Houllier A, Jolivet A and Milgrom E (1992) Variant forms of the pig lutropin/choriogonadotropin receptor Biochemistry $318377-8383$

Ziecik AJ, Stanchev PD and Tilton JE (1986) Evidence for presence of luteinizing hormone/human chorionic gonadotropin-binding sites in the porcine uterus Endocrinology 119 1159-1163

Ziecik AJ, Tilton JE, Espana F and Weigl R (1987) Effect of human chorionic gonadotropin on preovulatory luteinizing hormone surge and ovarian hormone secretion in gilts fournal of Animal Science 64 1134-1143

Ziecik AJ, Gajewski Z, Jedruch J and Barcikowski B (1993) Effect of human chorionic gonadotropin on myometrial electrical activity in the pig Animal Reproduction Sciences 31 131-139

Ziecik AJ, Ostrowska G, Kisielewska J and Zezula-Szpyra A (1995) Distribution and cycle phase dependency of gonadotropin receptors in musculature and blood vessels of the porcine broad ligament Experimental and Clinical Endocrinology and Diabetes 103 44-51 